A REVIEW OF SELECTED LAWS AND

GOVERNMENTAL PROGRAMS IN

COLORADO, AS RELATED TO MINERAL

RESOÜRCE MANAGEMENT AND

SURFACE MINING

Geological Survey

Geolozical Survey RESTMN, Vh 2092

Open-file report no. 76-649
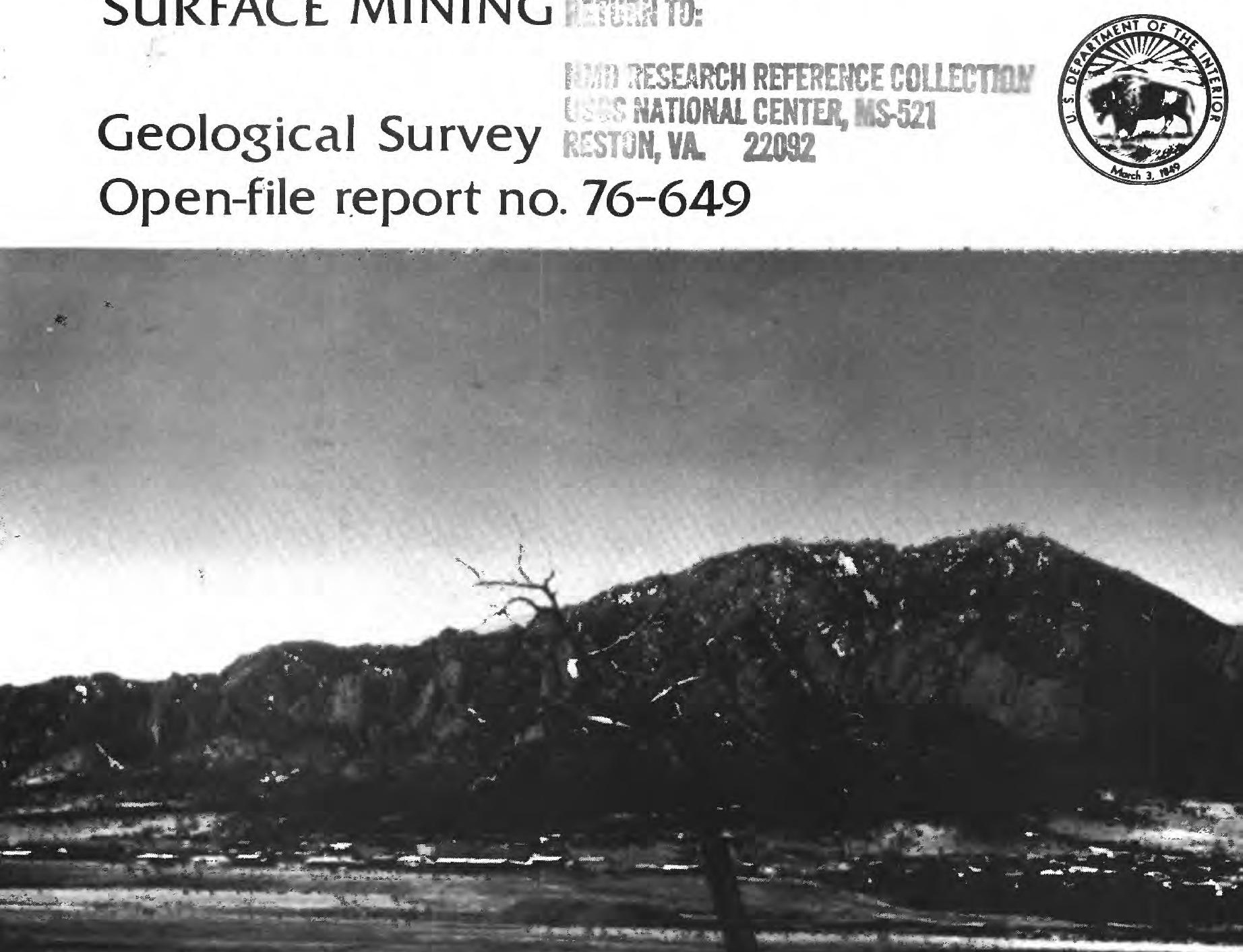

Resource and Land Investigations (RALI) Program (2) 
UNITED STATES DEPARTMENT OF THE INTERIOR

GEOLOGICAL SURVEY

A REVIEW OF SELECTED LAWS AND GOVERNMENTAL PROGRAMS

IN COLORADO,

AS RELATED TO MINERAL RESOURCE MANAGEMENT AND SURFACE MINING

by

Edgar A. Imhoff

Open-file report no. $76-649$

1976

Resource and Land Investigations (RALI) Program

National Center (MS-750)

Reston, Virginia 22092 


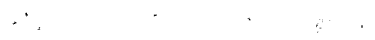




\section{CONTENTS}

Page

Abstract-..... 1

Introduction-

Purpose and Scope-1 2

Acknowledgements-_... 3

Overview-1.2. 3

Selected State Programs In Mineral Resources Planning-..... 4

Mineral Resources Extraction Planning-_......... 4

Critical Areas and Activities (H.B. 1041)-... 5

Mined-Area Reclamation-_... 7

Local Government-_. 7

The Weld County Mineral Resources Plan-_........ 9

City of Boulder Ordinance No. 4070 11

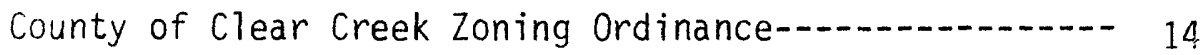

Selected References-_. 16 
Illustrations

Page

Figure 1. Map of Colorado showing geographical features and civil division boundaries mentioned in text

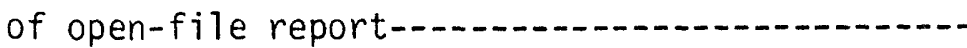

2. Photograph showing high-value residential area and esthetic qualities in Boulder, Colorado adjacent to planned sand and gravel operation---

3. Photograph showing agricultural area annexed by the City of Boulder under the condition that it be converted to a multiple-purpose public recreation area, with sand and gravel mining occurring as an interim land use-.................................... 13

Tables

Table 1. Local government regulatory activity under

H.B. 1041 -

Appendices

Page

Appendix A. Excerpt from Weld County Mineral Resources

Study-...-

B. Excerpt from Ordinance No. 4070 , City of

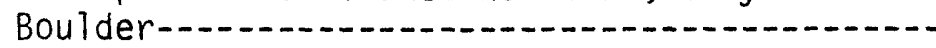

20

C. Excerpt from Clear Creek County Zoning Rules

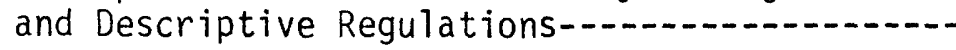




\title{
A REVIEW OF SELECTED LAWS AND GOVERNMENTAL PROGRAMS \\ IN COLORADO, AS RELATED TO MINERAL RESOURCE MANAGEMENT AND SURFACE MINING
}

Edgar A. Imhoff

\begin{abstract}
A review of selected laws and governmental programs in Colorado is presented in terms of their likely impact on surface mining activities. The review is based on interviews with governmental planners, analysis of statutes and technical reports, and field visitations in Colorado. State, regional and local activities were considered.

State programs found to affect surface mining in Colorado are based primarily on: the mineral resources planning provisions of Title 34-1304, CRS, 1973; the critical areas law set forth in House Bill 1041 of 1974, and; the mined-land reclamation act of 1976.

Each of the Colorado state programs are shown to rely on local initiative in setting objectives, in resource and related land planning, and in plan implementation through local law enforcement.

With the exception of mine reclamation (which is regulatory) the state program activities which were reviewed consisted largely of technical assistance, coordination, and proprietary functions.

In Colorado, most land use control powers have been delegated to local government. Several local governments, notably Weld County and the City of Boulder, have responded with the development of plans and plan implementation devices which guide private initiatives in mining, reclaiming and conversion of mined lands to productive land use.

Attention is focussed on a City of Boulder ordinance which formalizes cooperation between a mining company, The City, a state land trust, and (by implication) a federal agency in such a way that objectives of each cooperator are to be served as a 315 acre site is converted from present farmland, into a mine, and--ultimately--into a public open space and regional park.
\end{abstract}




\section{INTRODUCTION}

RALI (Resource and Land Investigations) is a program of the Department of the Interior served by a professional staff based in the U.S. Geological Survey. A principal mission of RALI is to improve the effectiveness and frequency of use of natural resources information in land use planning and decision-making. RALI produces both informational and methodological reports, with emphasis on the latter category. Subjects of RALI reports include, for example: natural resources inventory, environmental impact, critical natural areas, land use information systems, utility corridor routing, power plant siting, state resource management, coastal zone management, and mined-area reclamation.

In 1975, RALI contracted with the Energy Research and Development Administration for the services of the Argonne National Laboratory in a two-year study of mined-area reclamation and related land use planning. The objective of the study was to develop bibliographies and guidebooks on the state-of-the-art of integrated surface mining, reclamation, and land use planning. A guide to state mined-area reclamation has been published (Imhoff and others, 1976).

A division of labor was made with the Argonne National Laboratory, the USGS-RALI agreeing to provide most of the expertise on planning, while Agronne would address engineering and economic aspects of the study. Jointly, Argonne and RALI selected mine case studies in Arizona, Colorado, Florida, Georgia, Indiana, and West Virginia.

\section{PURPOSE AND SCOPE}

This report, which is based on a recent survey of Colorado planners and natural resource managers and a review of many planning documents, focuses on the nonfederal governmental planning activities in a case study state: Colorado. The report addresses the question, "How does nonfederal governmental planning affect surface mining in Colorado?" This question is posed on the premise that surface mining is an important transient land use in which planners will be interested increasingly as the competition for space, land and minerals intensifies in the years ahead.

State level planning is addressed broadly, whereas local activities that are particularly significant in revealing the state-of-the-art of ir.tegrated land planning and mine planning in the United States are discussed in detail. The report is directed at land and resource planners, wherever they work and regardless of affiliation. 


\section{ACKNOWLEDGEMENTS}

This report was made possible through the information and review provided by the following persons:

David Bucknam, Planner, Colorado Land Use Commission, Denver

Gary Fortner, Director, Dept. of Planning Services, Weld County, Greeley, Colorado

Edward McDowe11, Vice-president, Resources and Engineering, Flatiron Companies, Boulder

John Rold, Director, Colorado Geological Survey, Denver

Steve Schwochow, Geologist, Colorado Geological Survey, Denver

Wil Ulman, Director, Colorado Land Use Commission, Denver

Donald Walker, Director of Real Estate Services, City of Boulder

Berten Weaver, Planner, Phillips, Brandy \& Reddick, Denver

\section{OVERVIEW}

Minerals development, energy development, and a population boom are impacting Colorado, creating conflicts in land use and encouraging the search for devices to settle disputes through effective and efficient means. This search has been marked by a considerable amount of present experimentation in state legislation for planning and plan implementation (Ulman, oral communication, 1976). Some of the legislation and related programs are considered both as representative of the Rocky Mountain and Great Plains regions and as innovative nationally, especially with respect to mineral resources planning and land use planning.

Several programs of the State of Colorado are of interest, but, selected local governmental efforts are particularly valuable in showing innovations in mine planning, reclamation planning and related land planning. Although state programs cover many functions, analyses of statutes and regulations indicate that the state role in Colorado (with a few exceptions) is restricted to important but nonregulatory functions of technical assistance, funding, monitoring, reviewing, recommending and reporting. Essentially the State of Colorado has delegated public planning and plan implementation powers to local government. State powers to act in lieu of local government are limited. 
SELECTED STATE PROGRAMS IN

MINERAL RESOURCES PLANNING

Lawrence Malone (1975) lists the following functional kinds of active land planning programs in Colorado: growth policies, state land use planning, water management critical areas designation, surface mining regulations, power plant siting, new towns legislation, areas of statewide concern (greater than local concern), citizen involvement, determining existing land use, projecting land and resource needs, analysis of housing needs, and impact of policies on land resources. The Malone study fails to list another important category of state planning activity in which the State of Colorado is demonstrating leadership, namely: mineral resources planning.

The Colorado State programs having the potential of affecting surface mining significantly are: mineral resources extraction planning programs, the critical areas program, and the mined- area reclamation program.

\section{MINERAL RESOURCES EXTRACTION PLANNING}

Under Title 34-1-304, CRS (1973), Colorado counties in excess of 65,000 population (nine of 63 Colorado counties) are required to develop a plan for the extraction of commercial mineral deposits. General criteria set forth in the statutes include: commercial value, potential for effective multiple sequential use of the site (including off-site effects), quality of life, relationship to other plans, potential for full extraction, and potential for mined-land reclamation. The colorado Geological Survey has provided the technical assistance essential to enable the populous counties of Colorado to meet requirements of State law (Schwochow, 1974). The Colorado Geological Survey establishes criteria for classification and usually conducts the inventories and analys is of mineral depcsits.

The Colorado Geological Survey is a key agency also, in a second activity, which affects mineral resources planning: subdivision plat review. - The Survey is responsible for reviewing requests for plat approval to determine if the proposed development would preclude or interfere with the extraction of commercial minerals. According to Gary Fisher (oral communication, 1976) of the staff of the Colorado Land Use Commission, the plat review authority has been helpful in discouraging the preemption of sand and gravel deposits.

\footnotetext{
1/ A subdivision occurs in Colorado when land is divided into two parcels, or, with the development of a homesite on any one tract of land under 35 acres in size
} 


\section{CRITICAL AREAS AND ACTIVITIES (1041)}

House Bill 1041 of 1974, provides for State and local participation in the designation and regulation of critical areas and activities of greater than local concern. The State provides the guidance (Rogers and others, 1974) and means to enable local government to designate and to regulate the following type of areas and activities: mineral resource areas, natural hazard areas (flood, geologic and wild fire hazard areas), historical and archeological sites, wildlife habitat, airports, public utilities, highways, mass transit facilities, solid waste sites, new communities, water resources development projects and nuclear detonations. First-year reaction by counties to State mandates was reported by the Colorado Land Use Commission (1975) to have been sluggish, an appraisal which raises a question with regard to the State's ultimate recourse if counties do not act in matters of statewide concern. Arnold and McDonald (1976) observe that if the Colorado Land Use Commission"... finds that a locality fails to make a reasonable designation, it can ask the locality to reconsider or it can take local officials to court. "Such a request for designation has the effect, under $H B$ 1041, of creating a moratorium on all development (i.e.,--shutting off building permits, subdivision plats, zoning permits and the like). Bucknam (oral communication, 1976) reports that in six instances to date, such action has led to statelocal cooperation to seek agreemerit on designation of critical areas and activities for public controls, short of court action.

The 1041 program can lead to both the preclusion of mining and the protection of mineral deposits. Preclusion could occur, for example, through the designation of an archeological site of statewide significance. Protection could occur through the identification and designation of "mineral resource areas," as provided in HB 1041. Protection of mineral resources can also occur through restricting development in areas having geologic and flood hazards.

Several counties in eastern Colorado where population and mineral potential are low have asked to be exempted from certain requirements in 1041.

What has happened to date? By May 25, 1976, all of Colorado's 63 Counties had declared to the Colorado Land Use Commission their intentions to consider designation of mineral resource areas (Ulman, oral communication, 1976). Designations must be implemented through HB 1041 but most counties are using a variety of local land-use controls, especially zoning, and sub-division and flood-plain regulations.1/ Local government regulatory activity under HB 1041 is summarized in Table 1.

\footnotetext{
1/ Once a local government carries our the official act of "designating" they are locked into adopting regulations based upon and incorporating the procedures and criteria for administration found in HB 1041 . Zoning and subdivision regulations alone are not acceptable.
} 
TABLE 1

GUIDE TO LOCAL GOVERNMENT REGULATORY ACTIVITY UNDER HB 1041 , CUMULATIVE TO AUGIST 17,1976

County:

Bent County

Boulder County

Clear Creek County

Dolores county

Gunnison County

Huerfann County

La Plata County

Lincoln County

Louisville

Mesa County

Montezuma County

Phillips County

Pitkin County

Pueblo County

Yuma County
Activity or Area Designated and Regulated:

Mineral Resource Areas; Geologic, Flood, and Wildfire Hazard Areas

Site Selection of New Communities

Geologic and Flood Hazard Areas

Mineral Resource Areas, Geologic Hazard Areas

Site Selection of Airports

Mineral Resource Areas; Geologic, Flood, and Wildfire Hazard Areas

Mineral Resource Areas; Geologic, Flood, and Wildfire Hazard Areas

Site Selection and Construction of Major Facilities of Public Utilities

Geologic Hazard Areas (For Colorado Technological Center Area on ly)

Area Around Walker Field (Airport)

Mineral Resource Areas, Geologic Hazard Areas

Conduct of Nuclear Detonations, Areas Around Holyoke and Haxtun Airports

A11 21 Matters of State Interest except: Mineral Resource Areas, Areas Around Major Facilities of Public Utilities, Soils as a Geologic Hazard, Independence Pass Tunnel as a Historic Site, and Highway Interchange Areas

Site Selection of Highways, New Communities, Water and Sewer Systems, Mineral Resource Areas, Natural Hazard Areas

Flood Hazard Areas, Site Selection and Construction of Major Facilities of Public Utilities, Conduct of Nuclear Detonations 
In Colorado, all counties, except Arapahoe, Delta, Douglas, Garfield, Hinsdale, Moffat, and Montrose, have adopted local regulations to control development in mineral resource areas, geologic hazard areas, flood hazard areas, and wildfire hazard areas. These regulations conform to the guidelines for administration of those matters of state interest as specified in HB 1041 but generally use the authority of zoning and subdivision statutes or HB 1034.

\section{MINED-AREA RECLAMATION}

Colorado has enacted a mined-land reclamation bill (House Bill 1065) requiring all mine operators and prospectors to obtain state permits for extraction of minerals and disturbance of soils and overburden. Conditions of permit approval include mine planning and reclamation planning directed toward an end-use of the site agreed upon before commencement of mining. Importantly, the new act requires that state permits be in compliance with local zoning laws and plans. Procedures and standards for addressing the local planning requirement are yet to be developed.

\section{LOCAL GOVERNMENT}

In Colorado, powers of plan implementation are vested largely in local government. Accordingly, most land and minerals planning occurs at local levels. The State sets guidelines for the HB 1041 programs, but it is the County which designates areas of statewide significance and implements the designations. Similarly, in mineral resources planning it is the County which prepares and implements the mineral preservation plan.

Regulatory powers of municipalities are also significant because the economics of sand and gravel extraction dictate the location of some pits in close proximity to, if not in, the municipality exerting the demand.

The relatively key position of local government in Colorado in mineral resources planning was strengthened in 1975 with the enactment of HB 1706 which authorizes local governments to require master plans for mining and reclamation of property overlying commercial mineral deposits (John Rold, oral communication, 1976).

County government can also exert a major effect on the State minedarea reclamiation program, as indicated by statutory language, to wit:

"...the Department of Natural Resources shall not grant a permit in violation of city, town, county, or city and County (Denver) zoning and subdivision regulations." (sec. 5. 92-13-4, CRS, 1973) 


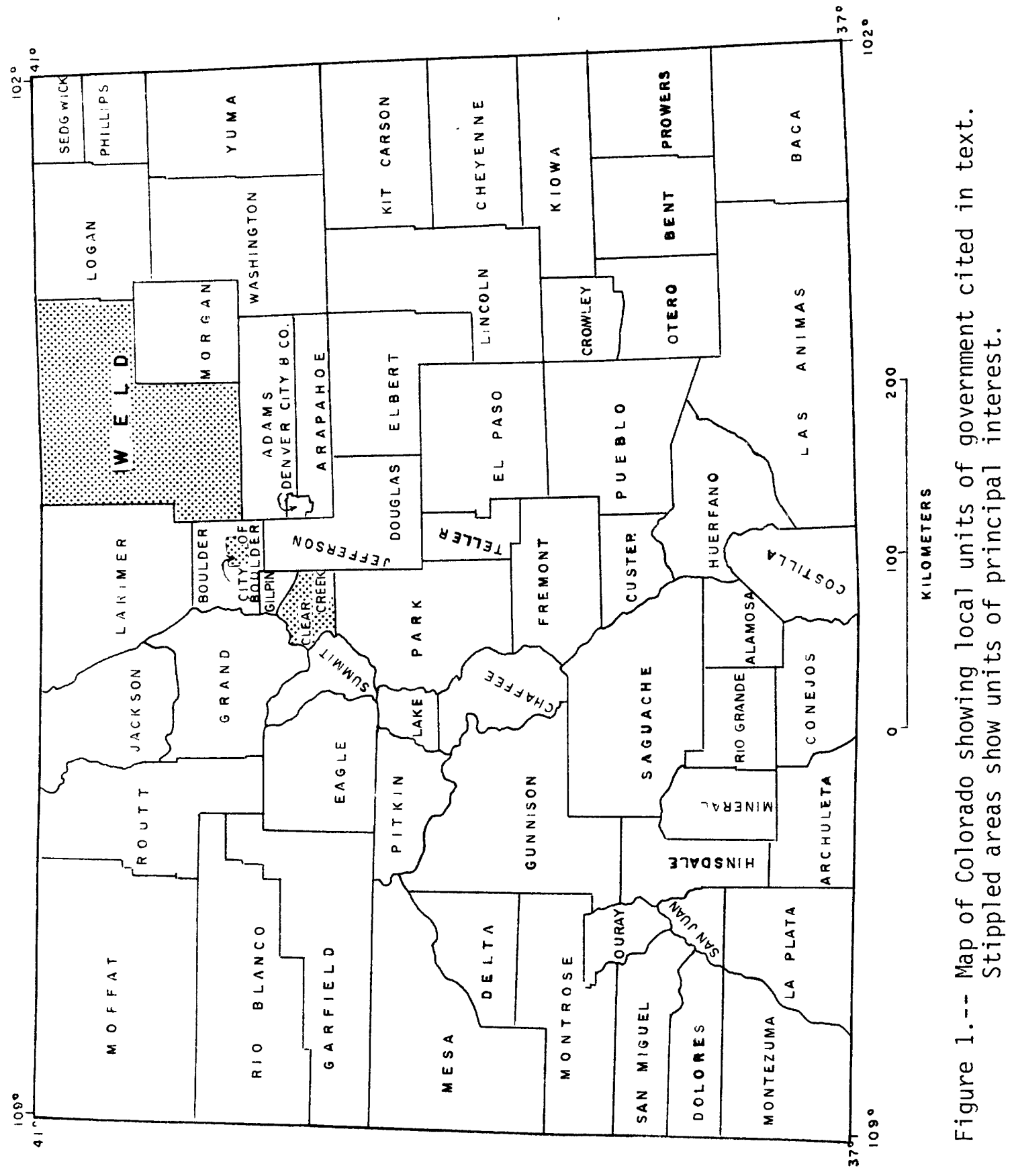


Three particular expressions of the powers of local government appear so innovative in technique and so promising in terms of intergovernmental and private cooperation that each is discussed in the following sections.

\section{THE WELD COUNTY MINERAL RESOURCES PLAN}

Weld County (figure 1) is an exceptional county in both agricultural productivity and as a gateway area to the Rockies. Greeley, the county seat, is an educational center and considered a good place to live. Weld county has been one of the first colorado counties to respond to the opportunity presented by the Title 34 program; Weld County has drafted and adopted (Oct. 8, 1976) a plan for the conservation and extraction of mineral resources, concomitant with protection of recognized agricultural values.

The mineral extraction plan is presented in two volumes. Volume I (1975) gives the results of detailed inventory and analysis based upon a classification of commercial mineral deposits provided by the Colorado Geological Survey and principles set forth in the Weld County Comprehensive Plan (1973). Several key findings of fact are noted about mineral occurrence and distribution, namely:

1. Most commercial sand and gravel deposits are found along surface water courses, either under flood plains or in adjacent stream terraces situated above the floodplains.

2. Some surface mining activities could conflict with prime irrigated lands; furthermore, the effect of large-scale mining on ground-water and, in turn, on irrigation, are unknown.

3. Sub-bituminous coal underlies a considerable area of the County and its stripping could lessen the value of agricultural lands significantly.

The general priniciples (adopted previously in the comprehensive plan) which support the statement of a mineral extraction plan for Weld county are excerpted from Volume I and presented as Appendix A. The principles (referred to as policies) are oriented toward a broad array of objectives, including food and fiber needs, mineral resources needs, environmental protection, and general welfare considerations. 
Volume II (1975) of the Weld County Mineral Resource Study, presents the physical plan for mineral extraction and conservation in Weld County. The purpose of the mineral extraction plan (Vol. II, page 4) is stated as: Conservation of mineral resources, reclamation of land integrated with mining operations, 1 protection of natura? resources such as water resources that might be affected by mining, and assurance of the establishment of end uses compatible with the Weld County Comprehensive Plan. The mineral extraction plan is expressed in map form to show location of sand and gravel deposits and strippable coal deposits, in relationship to irrigated and non-irrigated agricultural lands. Statements of standards and policies accompany the map and are presented as applicable also to minerals as yet undiscovered. General policies for plan implementation (pages 23-24) are:

- Access to future mineral resource development shall be considered in all land use decisions

- Surface mining is discouraged in prime irrigated lands, until such time as other mineral resources have been exhausted

- Surface mining will be accommodated in dry-land farming areas, as long as appropriate reclamation standards are observed

- Surface mining is encouraged, with appropriate standards, in floodplains

Detailed explanations are given of plan implementation devices, including: special use permitting of mining in land use zones set forth in the County Zoning resolutions, and; water augmentation agreement, in which a mining company agrees to compensate a public conservancy district for impact on water resources.

Gary Fortner (letter 1976) states that the intent of Weld County is "to phase reclamation so that it is concurrent with actual mining operations". 
The reputation of the City of Buuluer (figure 1) as being a founcainhead of environmental activism is well-known nationwide; thus, the enactment by the city of an ordinance annexing open space adjacent to a suburban residential area (figure 2) and simultaneously issuing a special permit for gravel extraction in the annexed area (figure 3 ) must come as a shock to some planners and developers. Substantive portions of the ordinance are attached as Appendix B. In discussing events leading up to the passage of the ordinance, Don Walker (oral communication, 1976) cited tens of meetings held over several years time and a tortuous process of cooperative effort between the City and the mining company, the flatiron Companies, in proceeding through a maze of work sessions and public hearings involving many public groups and private citizens. The result seems to represent a pareto optimum of sorts in which each of the principal parties seem to have won.

The principal involved partieslare; the Flatiron Companies, the City of Boulder, the Colorado Open Land Foundation, and the Federal Bureau of Outdoor Recreation. It is interesting to consider what each party may roceive as benefit from the annexation, zoning and proposed mineral extraction.

Briefly, The Companies win the right to mine about seven million tons of sand and gravel over a 20-year period. In addition, in an action related to the ordinance (McDowell, oral communication, 1976), The Companies plan to give a scenic easement of 315 acres to a nunprofit organization, the Colorado Open Land Foundation, sbiect to a favorable ruling by the Federal IRS. The Companies plan to use the value of the gift--essentially, the mine site--as a charitable contributiun. Also the Companies presently own additional land adjacent to the extraction site. This land will probably be enhanced by the parkland open space which will result from accomplishment of the reclamation plan stipulated in the ordinance.

\footnotetext{
$1 /$

The term "principal involved parties" is admittedly a gross generalization not applicable to some people interested and involved in such issues as the Boulder Case represents. We do not discuss, for example, the interest or involvement of homeowners presently living near the annexed property, although the record of hearings indicated consideration of their interests.
} 


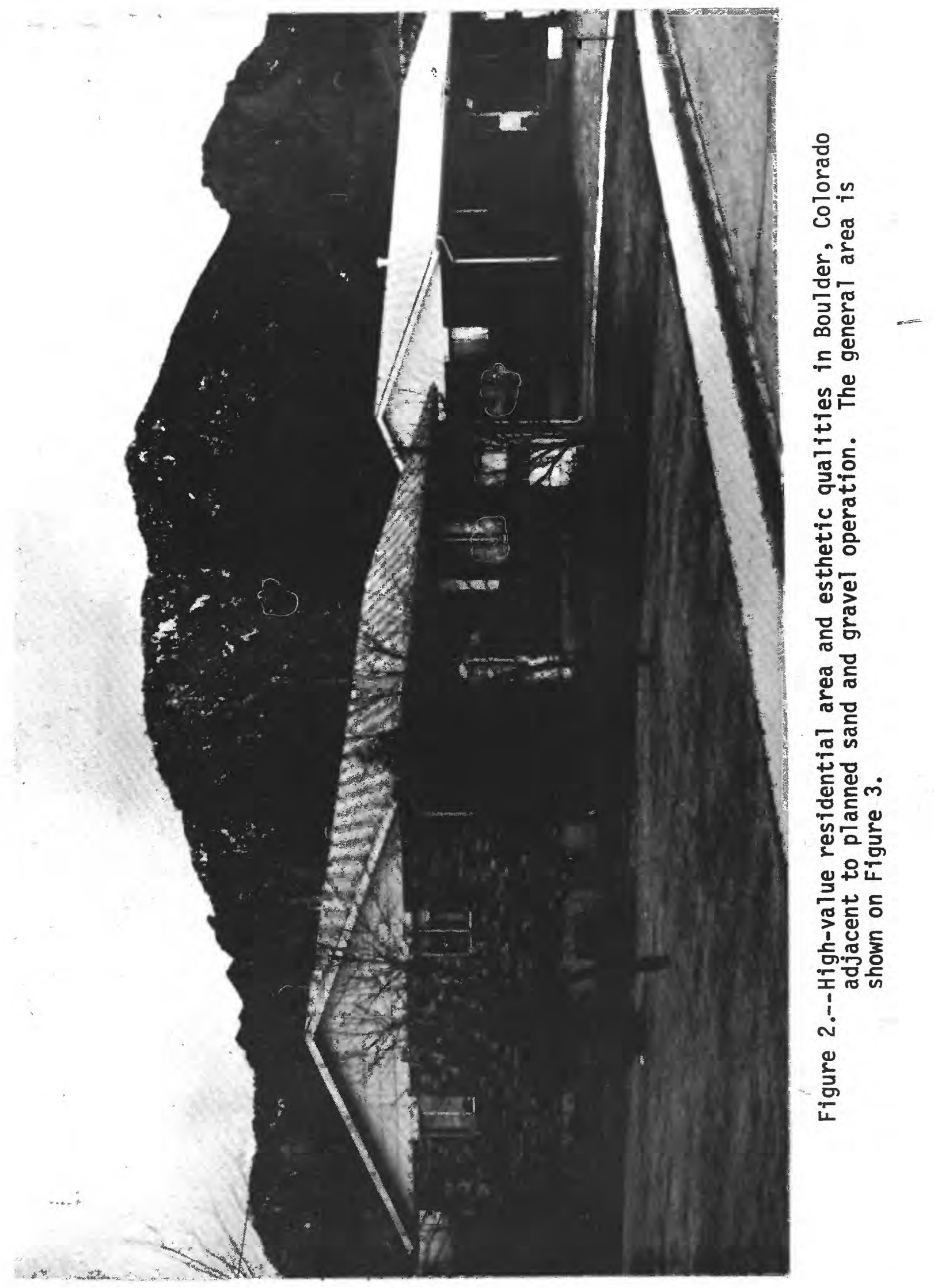




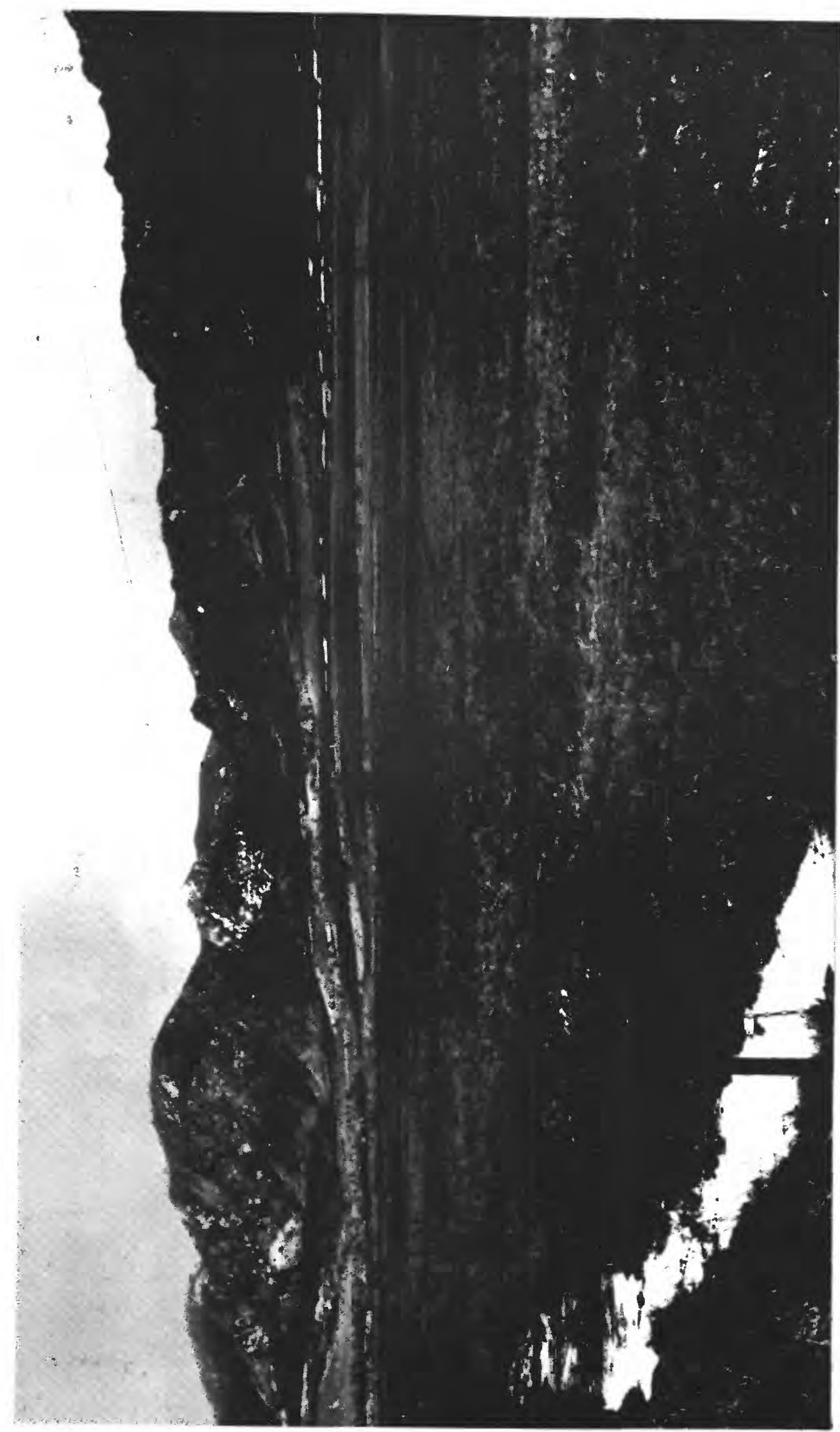

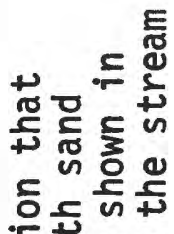

中. - 38 प्र 잉 일 为 凹 도동 느으오 홍 헝 므묘 डับ 就 원 용 与. U 듕 은 을 40 지 ○ 온

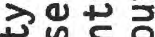
눙드 잉 문 แ 立 든 용 a 긍 웅 드음ㅁㅁㅁ Q들 ํㅣㅌ ํㅗㄷ हه 다잉 ○ 에 믕 ช 웡ㄷㅇ +. бo

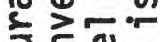

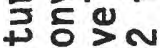
$=0$ \% Јับ 으 묻

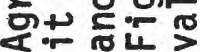
!

竞 
The City of Boulder wins, in a sense, the construction materials necessary for building in and around Boulder. The City will have increased tax revenue (for a while, anyway) from the site and tax on the mineral extracted. Lastly, the City gets planned, staged development of a parkland - open space over a 20-year period. By staging the reclamation and transfer of ownership, the City places itself in a favored position to obtain Federal matching funds (for the value of the land) so that the park can be equipped fully with user facilities as each segment, is mined-out, is reclaimed, and becomes available for public use.

The Colorado Open Land Foundation has become a vital agent of the implementation design for, acting as an escrow agent, it can release segments of the gift land to the City to match value with the Federal government, at the rate at which Federal funds are available.

The principal winnings to be realized by the Colorado Open Land Foundation and the Federal Bureau of Outdoor Recreation are attainment of purpose. The Foundation exists to promote public open space in colorado. The Bureau exists to help the nation assess and meet its outdoor recreation needs. Both organizations are served by the ordinances and contractual segments occurring in Boulder, Colorado; and, they have been active in such arrangements.

\section{COUNTY OF CLEAR CREEK ZONING ORDINANCE}

Clear Creek Councy, located in the Colorado Front Range west of Denver, is both an historic and active mining area. The clear Creek County Board of Commissioners, reportedly alarmed at the encroachment of residences and recreational developments into "mining country" in Colorado, have hired planning and legal consultants and have adopted an unusual zoning ordinance. In response to numerous local public hearings, the planning firm of Phillips, Brandt and Reddick and the Tigal firm of Hackethal, McNeill and Auco in prepared an ordinance which, with certain exclusions, rezoned all patented and otherwise active mining claims into a "Mining-One" district. Almost a quarter of the entire county is thereby zoned for mining.

All non-mining uses are held as potentially incompatible with mining and, with the exception of future residences permitted under previous zoning, would be allowed only after a public hearing which will carefully analyze likely impacts upon future mineral extraction. Even prospcctive owners and builders of the future residential uses permitted under previous zoning will be notified (through the building permit procedure or through other "early warning devices") that present or future mineral extraction activities will not be held responsible for the incompatibilities of future land uses. 
According to planner, Berten Weaver (oral communication, 1976), the ordinance represents the dominant view in the County that mining is a preferred land use. It is planned that the zoning maps will be posted prominently to show that Clear creek County "is mining country."

An excerpt from the ordinance is attached as Appendix $C$. 


\section{SELECTED REFERENCES}

Arnold, Michael and McDonald, Ann B., editors, 1976, A

Summary of State Land Use Controls December, 1975: Washington, DC, Plus Publications.

Colorado Land Use Commission, 1974, Report to the Colorado General Assembly on Local Government Progress under House Bil1 1041:

Denver, Colorado, 74 pages.

Malone, Lawrence P., 1975, Survey of State Land Use Planning Activities, a report prepared by the American Institute of Planners for the U.S. Department of Housing and Urban Development, Research Contract =2275: Washington, DC, December 22, 1975, 45 pages.

Schwochow, S.D., Shroba, R.R., and Wicklein, P.W., 1974, Sand, grave1, and quarry aggregate resources, Colorado Front Range counties: Colorado Geological Survey Spec. Pub. 5-A, 43 pages, 3 pls.

Weld County, Colorado, Board of County Commissioners, 1973, Weld County Comprehensive Plan, 138 pages.

Weld County, Colorado, County Planning Commission, 1975, Weld County Mineral Resources: Greeley, Colorado, Volumes I and II, 98 pages and 47 pages, respectively. 


\section{APPENDIX A}

EXCERPT FROM WELD COUNTY MINERAL RESOURCES STUDY, VOL. I, 1975, pp. 60-63

Resource Management Policies

(1) Access to future mineral resource development shall be considered in a 11 land-use decisions. The location of mineral deposits and their importance shall be determined in cooperation with the Colorado Geological Survey.

(2) Any land use that will pollute any stream, body of water, subsurface aquifer, aquifer recharge, the air or the surrounding surface will require the development of a proper treatment facility or environmental protective operation before said land use can be allowed.

(3) A11 proposed changes of land use will be supported by an accompanying environmental impact statement prepared by recognized experts.

(4) Lands shall not be mined unless a rehabilitation plan is approved by the Board of County Commissioners.

(5) Agriculture is considered a valuable resource in Weld County which must be protected from adverse impacts resulting from uncontrolled and undirected business, industrial and residential growth. In order to maintain and promote this important segment of the county's economy, the cultural and human values associated with farm life and the overall benefits of an agricultural environment, any uses of prime irrigated farmland for uses other than agricultural will be critically reviewed to insure the proposed development will not adversely impact the agricultural interests of the County and that the development will positively contribute to the over-all economy environment and tax base of the county.

(6) Because adequate water supplies are essential for agricultural production, each nonagricultural development will be encouraged to obtain its necessary water from sources which are considered nonessential to the maintenance of agricultural production in this particular area. In support of this concept, highest priorities will be given to those developments that have low rates of water consumption. In pursuit of these objectives, it will be the policy to obtain comments from those ditch companies, water districts and other water resource agencies which maintain records and control the transfer of water properties in a particular area.

(7) Flood plains and other unsafe or unsuitable areas for building shall be kept open and free to accommodate the acts of nature. 


\section{Development Policies}

(1) In order to minimize conflicting land uses and minimize the cost of new facilities and services to the taxpayer, industrial, commercial, business and residential development will be encouraged to locate adjacent to the existing 27 incorporated towns and in accordance with the comprehensive plans and stated wishes of each community. Where new developments desire to locate in the rural areas away from the existing municipalities, they will be required to justify their development with a detailed plan (Planned Unit Development) accompanied by an environmental impact statement prepared by recognized experts, showing all details of how the proposed development would aifect the local and county's economic base, the tax revenues and cost of public services, such as schools, utilities, roads and health services, and the immediate and long-term impact on the existing environment.

(2) New residential developments which are not closely connected to and served by municipal utilities and services shall be discouraged.

(3) Proposals for new residential development, adjoining existing municipalities shall be encouraged so long as they conform to the desires of the towns as expressed in their comprehensive plans.

(4) Existing municipalities are the best and most efficient sources of public goods and services which are necessary to serve new residential developments. These municipalities will be encouraged to improve their ability to serve new developments and will be looked to for service of all new developments within their corporate areas, in annexable areas immediately adjacent to the town and even those areas not immediately available for annexation, but within a reasonable service distance from the municipality.

(5) Commercial development will not be encouraged in the unincorporated areas of the county unless it can be shown by the developer that the proposed commercial use cannot reasonably be located in an urban area.

(6) Commercial development designed to serve the agricultural base of the county should be located wherever practical within a municipality; however, whenever distance from a municipality makes this impractical or unprofitable, establishment of such commercial service, facilities within easy access to each agricultural area will be encouraged. 
(7) Auto-oriented commercial services will be encouraged to locate either within existing municipalities or at well planned and located areas along the major highways and thoroughfares. When located outside the municipalities, the developer will be asked to furnish justification of the need for the proposed commercial facility and to show, through a detailed Planned Unit Development approach, how the development will accommodate the traveling public without interference with the ongoing traffic.

(8) Detailed development plans will be needed along with an economic impact statement and an environmental impact statement prepared by recognized experts, for the development outside the municipal areas to be considered by the Weld County officials.

(9) Zoning for industrial use in areas outside the areas covered by the comprehensive plans of the existing municipalities shall be encouraged only for low employee concentration, agriculturally related industries or other industries that can show they cannot reasonably be accommodated within the areas covered by the municipalities' comprehensive plans.

(10) Highly productive, irrigated, agricultural lands shall not normally be rezoned for industrial use. Only when detailed development plans accompanied by economic and environmental impact statements, prepared by recognized experts, justify the sacrifice of these agricultural assets will such a rezoning request receive favorable consideration.

(11) Industrial zoning within the comprehensive planning area of a town shall be subject to the industry's compliance with the local comprehensive plan and an agreement to annex to the town reached between the town and the developer prior to the change of zoning.

(12) A11 industrial zoning requests must be supported by a detailed development plan and an economic and environmental impact statement.

The purpose of comprehensive plans is to provide a framework in which decisions regarding land use can be made. Such plans are used to evaluate public and private development proposals with reference to their impact on the over-a11 anticipated development of the individual jurisdiction. 
APPENDIX $B^{\underline{1}}$

EXCERPT OF ORDINANCE NO. 4070, CITY OF BOULDER, FEB. 23, 1976

\begin{abstract}
AN ORDINANCE ANNEXING TO THE CITY OF BOULDER
CERTAIN TERRITORY, ZONING AND INCLUDING

THE SAID TERRITORY IN A-E, AGRICULTURAL-

ESTABLISHED, AND ISSUING A SPECIAL REVIEW

USE IN PART OF SUCH TERRITORY FOR GRAVEL

EXTRACTION AND RELATED ACTIVITIES THEREFORE,

AMENDING THE ZONING DISTRICT MAP TO INCLUDE

THE SAID TERRITORY IN THE ZONING DISTRICT

HEREINABOVE MENTIONED: AND SETTING FORTH

DETAILS IN RELATION THERETO.
\end{abstract}

Section 1. A public hearing was duly held in a11 respects according to law before the City Council on June 17, 1975, and the City Council considered the evidence presented at the said hearing, and based thereon, the City Council, as contained in Resolution No. 186, found and does hereby find and determine: that the territory proposed for annexation pursuant to the Petition for Annexation meets the applicable requirements of C.R.S. 1973, $\S\{31-8-104$ and 31-8-105, and further, that:

(a) Not less than one-sixth of the perimeter of the territory proposed to be annexed is contiguous with the City of Boulder.

(b) The territory proposed to be annexed shares a community of interest with the City of Boulder, is urban or will be urbanized in the near future, is integrated or capable of being integrated with the City of Boulder.

(c) In establishing the boundaries of the territory proposed to be annexed, no land held in identical ownership, whether consisting of one traci or parcel of real estate, or two or more contiguous tracts or parcels of real estate, has been divided into separate parts or parcels without the written consent of the landowners thereof, unless such tracts or parcels are separated by a dedicated street, road, or other public way.

1) Various appendices to the ordinance, cited herein, have been deleted to reduce the size of copy. 
(d) In establishing the boundaries of the territory proposed to be annexed, no land held in identical ownership, whether consisting of one tract or parcel of real estate, or two or more contiguous tracts or parcels of real estate, comprising twenty acres or more which, together with the buildings and improvements situated thereon, have a valuation for assessment in excess of $\$ 200,000$ for ad valorem tax purposes for the year next preceding the filing of the petition, has been included within the said territory without the written consent of the landowners.

(e) The territory proposed for annexation does not include an area included in another annexation proceeding involving the City of Boulder or a city other than the City of Boulder.

(f) Inasmuch as the present proceedings are pursuant to a Petition for annexation, which petition contains the signatures of all the landowners involved, an annexation election pursuant to $\S \S 31-$ 8-107 (2) and $31-8-112$, C.R.S. 1973, is not required.

Section 2. The City Council in addition finds, determines and concludes:

(a) The Planning Board after holding a public hearing has duly submitted to the Council an advisory report and recommendation for the annexation, A-E, Agricultural-Established, zoning, and special review use permit for the territory, and recommends affirmatively thereon;

(b) The area proposed for annexation is in the immediate environs of the City and activity on the land should be subject to City control, and annexation is therefore appropriate;

(c) That a large portion of the area proposed for annexation has a gravel deposit of high quality. It is now available for extraction and there is a need for gravel. It is a reasonable certainty that the gravel will be extracted now or in the future. It is preferable to permit the extraction now rather than later when the surrounding area will have developed further;

(d) The terms and conditions on the special review use are designed to minimize the impact upon the neighborhood and community as a whole;

(e) The extractive use, and the open space use of the land after reclamation, will be of optimum benefit to the landowner, the neighborhood and surrounding area, and the community as a whole;

(f) The zoning of the entire area being annexed is consistent with the planning therefor; 
(g) Approval is consistent with the policy of state law to see that commercial mineral deposits are extracted and put to beneficial use, and the land then reclaimed;

(h) All documents necessary to protect the public interest have been executed and delivered and the City Council approves the same;

NOW, THEREFORE, BE IT ORDAINED BY THE CITY COUNCIL OF THE CITY OF BOULDER, COLORADO:

Section 3. The following territory, situated in the County of Boulder, State of Colorado, be, and the same hereby is, annexed to, and included within, the corporate boundaries of the City of Boulder:

\section{(1and description deleted)}

Section 4. Chapter 37, "Land Use Regulations," of the Revised Code of the City of Boulder, 1965, as amended, and the zoning district map forming a part thereof, be, and the same hereby are, amended to zone and include the territory described in Section 3 hereof from its present zoning to A-E, Agricultural-Established, as provided in Chapter 37.

Section 5. Pursuant to Chapter 37, "Land Use Regulations," of the Revised Code of the City of Boulder, 1965, as amended, approval for a special review use to conduct an extractive industry is hereby granted, subject to the conditions set forth in Section 6 through 9, inclusive, on the following-described land:

\section{(land description deleted)}

Section 6. Conditions to which the Use will Be Subject.

6.1 Conditions Applicable to the Mining Process.

6.1.1 Mining to be Conducted in Stages.

Mining will be conducted in various geographical portions of the premises, which geographical portions are referred to as stages. The various stages are set forth in Appendix A, (deleted from this report). Stage one will be the first stage to be mined, and stage two north will follow, stage two south will follow stage two north, stage three will follow stage two south, stage four will follow stage three, and stage five will follow stage four. 
Mining and reclamation shall be conducted to substantial completion within each stage before mining is commenced in any other stage; except that operations preparatory to mining may be commenced in the next stage when mining and reclamation in the previous stage are within 180 days of substantial completion. Such preparatory operations include, but are not limited to, trenching and the removal of overburden. The term "completion of mining" shall mean excavation of all reasonably available sand and gravel within the area to be mined to within eight inches above the underlying shale. Reclamation shall be deemed substantially completed when all grading, initial seeding and initial planting in that stage have been completed, except for the construction, seeding, and planting of landforms and areas to be reclaimed by use of overburden from the next subsequent stage. If the City Manager, with the concurrence of the City Council, determines that mining and reclamation on the preceding stage have not been substantially completed prior to the commencement of mining on the next stage, the City Manager may issue a "shutdown of operations" order as to this next stage in accordance with paragraph 9.3.3 to prevent any further mining operations until the substantial completion of mining and reclamation on the previous stage.

Each stage shall be mined and reclaimed in sequence, with reclamation of areas mined, within the stages, to be carried out as set forth in paragraph 6.2.1. Reclamation shall occur concurrently with mining, to the extent practical. The term "reclamation" shall mean and include all steps, processes, activities and results set forth in paragraphs 6.2.1 to 6.2.4, inclusive, plus construction of the improvements set forth in paragraph 6.10. Should the reclamation of the preceeding stage not be proceeding in accordance with all plans, timing and specifications contained herein, the City Manager may issue a "shut-down of operations" order in accordance with paragraph 9.3.3 to prevent any further mining operations until the reclamation on the previous stage is brought into compliance.

Prior to the commencement of any mining or preparatory operations in stage one, Flatiron shall completely construct the berm along the Turnpike located in stage one, according to the plans and specifications set forth in paragraphs 6.2.1, 6.2.2 and in compliance with paragraph 6.2.4 The plant and settling ponds may be constructed on stage five prior to the commencement of the mining on stage cne. 


\subsubsection{Timing for Mining.}

\subsubsection{Time Limit for Initial Construction.}

Construction of the plant site, settling ponds and the visual screening referred to in paragraph 6.2 .3 shall be commenced prior to the first 0ctober 1st following approval of the use by special review and all related permits or termination of any litigation contesting the validity of same, whichever is later.

\subsubsection{Time Limits for Each Stage.}

Following are the time limits for mining on each stage:

\begin{tabular}{|c|c|c|}
\hline STAGE NO. & COMMENCEMENT TIME & COMPLETION PERIOD \\
\hline 1 & $\begin{array}{l}\text { Not later than } 24 \\
\text { months after the } \\
\text { commencement of } \\
\text { construction on the } \\
\text { plant site as de- } \\
\text { scribed in para- } \\
\text { graph } 6.1 .2 .1\end{array}$ & $\begin{array}{l}\text { Not later than } 3 \\
\text { years after mining } \\
\text { on stage one was } \\
\text { commenced. }\end{array}$ \\
\hline $2 \mathrm{~N}$ & $\begin{array}{l}\text { Not later than } 3 \\
\text { years after mining } \\
\text { on stage one was } \\
\text { commenced. }\end{array}$ & $\begin{array}{l}\text { Not later than } 6 \\
\text { years after mining } \\
\text { on stage one was } \\
\text { commenced. }\end{array}$ \\
\hline $2 S$ & OPEN & $\begin{array}{l}\text { Not later than } 3 \\
\text { years after mining on } \\
\text { stage two south was } \\
\text { commenced. }\end{array}$ \\
\hline 3 & OPEN & $\begin{array}{l}\text { Not later than } 20 \text { years } \\
\text { after mining on stage } \\
\text { one was commenced. }\end{array}$ \\
\hline 4 & OPEN & $\begin{array}{l}\text { Not later than } 20 \text { years } \\
\text { after mining on stage } \\
\text { one was commenced. }\end{array}$ \\
\hline 5 & OPEN & $\begin{array}{l}\text { Not later than } 20 \text { years } \\
\text { after mining on stage } \\
\text { one was commenced. }\end{array}$ \\
\hline
\end{tabular}




\subsubsection{Overall Time Limit.}

Except as hereinafter set forth, mining shall be concluded not later than 20 years after mining on stage one was commenced. All equipment, stockpiles and plant buildings shall be removed from the premises no later than 22 years after mining on stage one was commenced. Reclamation of the premises shall be promptly completed in accordance with paragraphs 6.2 .1 and 6.2 .2 of this permit.

It is understood that this permit is expressly contingent upon issuance of, and compliance with, all applicable state permits with respect to each and every stage of this proposal. Flatiron shall commence immediately and diligently process the applications for all such permits.

\subsubsection{Extensions of Time--Market Conditions}

The time limits contained herein are specific and must be conformed to; however, the City recognizes that market conditions beyond Flatiron's control may prevent it from being able to sell all the sand and gravel to be excavated from the premises within 20 years from the commencement of mining on stage one. Therefore, the City Manager, with the concurrence of the City Council, upon petition by Flatiron and presentation of sufficient evidence of the conditions set forth below, may grant an extension of time during which the permitted use shall be allowed for the mining and reclamation of stages two south, three, four or five, but in no event shall the period of use be extended beyond two years from mining and removal termination dates as referred to in paragraph 6.1.2.3 The City Council may, however, by motion or resolution, grant up to an additional three years beyond the said two years on the same terms and conditions.

\subsubsection{Conditions for Extension of Time.}

If less than 10.5 million tons of sand and gravel, escavated from Flatiron pits in the production areas, are sold between January 1, 1976, and January 31, 1990, then Flatiron shall be granted an extension of 180 days for each full 350,000 tons by which the actual sale figure is less than 10.5 million, but in no event shall the period of use be extended by the City Manager with the concurrence of the city Council beyond two years from mining and removal termination dates as referred to in paragraph 6.1.2.3 The City Council may, however, by motion or resolution, grant up to an additional three years beyond the said two years on the same terms and conditions. 
"Flatiron pits" as used herein shall be defined as sand or gravel deposits or mines now or hereafter owned by Flatiron or leased by Flatiron as the operator; the term "Flatiron" shall include entities controlled by or under common control by Flatiron.

"Production area" as used herein shall be described as that portion of Boulder County, Colorado, lying between the county line on the south and west, on the north; and the county line on the coast.

"Sand and gravel excavated and sold or used from Flatiron pits" as used herein shall include sand and gravel used or sold as part of concrete and road construction or surfacing materials and asphalt paving or other products, as well as sand and gravel sold without combination with other materials.

Nothing herein is intended to limit Flatiron's market area for sand and/or gravel mined on the premises.

\subsubsection{Extension of Time--Natural Catastrophe.}

The City Manager, with the concurrence of the City Council, upon petition by Flatiron and presentation of sufficient evidence, may extend the dates by which Flatiron is required to complete any item required herein because of delays caused by flood, fire, strike, windstorm, war, civil disorder, national or local emergency, inavailability of fuel or materials, or other cause of catastrophe beyond the reasonable control of Flatiron, if such delay affects the premises. In no event shall the period of use be extended beyond two years from mining and removal termination dates as referred to in paragraph 6.1.2.3. The City Counc il may, however, by motion or resolution, grant up to an additional three years beyond the said two years on the same terms and conditions.

\subsubsection{Method of Mining.}

All stages will be mined using a dry excavation process. Dry excavation and dewatering are defined as follows:

having been dewatered. After Sry Excavation: Mining within a site by means of equipment working into the unmined face of gravel, loaded into trucks, scrapers, or conveyor system, and carried to the processing plant. Gravel strata is excavated down to within approximately 0.8 feet from underlying shale so that a tractable running surface for loaders and other wheeled equipment can be maintained. 
Dewatering: Removal of ground water from gravel strata by draining it into a peripheral dewatering trench. The trench is excavated below the gravel strata into shale and is sloped to drain to one point, or sump, where the collected water is pumped into the nearest receiving water body or used for reclamation or dust abatement. The dewatering trench "cuts off" the flow of ground water into the mining site and allows the interior to drain.

Following the completion of mining in each stage, Flatiron shall modify, as necessary, the dewatering facilities to accomplish the reclamation plan for that stage. In no event and at no time shall the City be obligated to operate and/or maintain and ground water pumps or pumping station.

\subsection{Reclamation of Mined Area, and Visual Screening of the Areas to be Mined.}

6.2.1. Landforms to be Completed Within Each
$\frac{\text { Stage After Completion of Mining Within }}{\text { that Stage; Time Limits for Completion }}$
of Landforms.

Flatiron shall construct within each stage in areas, which have been mined, those landforms described in Appendix B (deleted from this report). The landforms which are to be constructed on areas on which mining has been completed as of any November 30 shall be constructed on or before the following June 1; except for landforms on areas used as roads, landforms in areas which will necessarily be disturbed by future mining in the same stage, and landforms which cannot be completed because the necessary overburden must come from future mining within the same or next stage. Landforms shall be covered with topsoil in the manner and amount set forth in paragraph 3 of "Planting Instruction for Native Grass Areas" cci tained in Appendix C (deleted from this report). All landforms shown in connection with a particular stage shall be completed within 180 days after actual completion of mining in that stage, or 180 days after the date when mining is required to be completed in that stage (if mining has been commenced in that stage), whichever sooner occurs.

All completed landforms shall be planted in accordance with paragraph 6.2.2. Flatiron shall use its best efforts and diligence to ensure that mining in the area of a particular landform is completed by November 30 , so that landforms can be promptly constructed and planted in accordance with this paragraph.

See paragraph 9.3.3 concerning shutdown of mining operations (and other sanctions) if reclamation requirements are not met. 
6.2.2. Landscaping Materials to be Planted Within Each Stage; Time for Completion of Landscaping; Replacement of Plants Which do not Survive.

Flatiron shall supply and plant within each stage which has been mined and on which landforms have been constructed, the landscaping materials described in Appendix C. Flatiron and the City Manager, or his delegate, with the concurrence of the City Council, by mutal agreement, may vary the species to be originally planted or used as a replacement in light of survival experience and availability of the various species and hybrid species which may be developed. Landscaping materials shall be planted within the following time limits: Landscaping materials which are to be planted on areas on which mining has been completed as of any November 30 shall be planted on or before the following June 15; except for materials to be planted on landforms which are not required to be completed on that June 15 .

All landscaping materials required to be planted within a particular stage will be planted on or before that June 15 which next succeeds the first November 30 as of which mining has been completed in the particular stage.

All trees and shrubs which are not alive or have not "broken bud" on the first June 16 which is more than one year after date of planting will be replaced by Flatiron on or before the following June 16. Bare spots in grass plantings which exist on the first March 30 which is more than three months after date of planting shall be appropriately reseeded by Flatiron on or before the following June 16. Flatiron will make only one such replacement of any required tree, shrub or grass planting. Flatiron will install, operate and maintain an adequate drip irrigation system irrigating planted trees and shrubs for three years after date of initial planting, to maintain vitality of trees and shrubs. All replacements shall be of equal size as those being replaced. At the end of the three-year period, Flatiron shall leave in place any buried piping which is part of the system, but shall have no further obligation to operate or maintain same.

Replacements required pursuant to the preceding paragraph will be of the same species and size as originally required, unless mutually agreed by Flatiron and the City Manager with the concurrence of the City Council; provided, however, that if any juniperus virginiani scopulorum or $p . j$. juniperus cheninsis pfitzer is required to be replaced in stage one, Flatiron may replace juniperus virginiani scopulorum with any of the following: cottonwood, Russian olive, green ash, or New Mexico lucust; and may replace p.j. juniperus cheninsis pfitzer shrubs with a specimen of any of the following: chokecherry, smooth sumac, or skunkbush. If Flatiron elects not to replace with evergreens, then the City Manager, with the concurrence of the City Councll, shall determine which of the alternate species shall be used. Replacements shall be of a size similar to that of the specimen being replaced. 
In addition to the replacement requirements set forth above, Flatiron shall replace dead trees and shrubs so as to meet the following requirement. On the first June 16 which is more than three years after the date when mining is completed in any stage, the number of trees and shrubs required to be planted in that stage which have "broken bud" shall be counted. If the number of trees or shrubs which have broken bud is less than $80 \%$ of the number of trees or shrubs required to be planted in that stage, then Flatiron will replant the number of trees equal to the deficiency from $80 \%$, and in addition, Flatiron will replant a number of trees which is equal to the deficiency from $80 \%$ multiplied by the percent of the total required trees which died after planting or had not broken bud at date of count. For example, if 200 trees were required to be planted on a particular stage, on date of count 140 trees had broken bud and 10 trees had previously died and been replaced, the Flatiron would replant that number of trees which is calculated as follows:

Required Plantings:

80 of required plantings:

Trees which had broken bud on date of count:

Deficiency of Trees which had broken bud from $80 \%$ of those required:

Percent of trees planted which previously died or had not broken bud on date of count:

Had not broken bud on date of count

Previously died and were replaced:

Total:

70 is $35 \%$ of 200 , the required number.

$35 \%$ of 20 (the deficiency from $80 \%$ ) is

So total trees replanted would be 20 plus 7 , or 
The number of shrubs to be replanted will be similarly calculated.

The replanting shall be accomplished on or before that June 15 which next follow the June 16 when the count is to be made. Flatiron may perform any or all. of the replanting in advance of the date when the count is to be made. Flatiron will choose which trees and shrubs are to be replaced in order to make the required number of replantings.

See paragraph 9.3.3 concerning shutdown of mining operations if reclamation requirements are not met.

\subsubsection{Visual Screening.}

\subsubsection{Screening along U.S. 36}

Prior to commencement of preparatory operations or mining within stage one, Flatiron will construct the berm on stage one described in Apperidix B. The landforms shall be covered with sufficient topsoil which is removed in the process of removing overburden. Flatiron will plant thereon the landscaping materials described in Appendices $B$ and $C$ within the time limits hereinafter set forth. Flatiron and the City Manager, or his delegate, may, by mutual agreement, vary the species to be originally planted or used as replacements, in light of survival experience and availability of the various species and any hybrid species which may be developed. Construction will be completed prior to commencement of mining (except such mining as is necessary for construction of the landforms). All provisions of paragraph 6.2 .2 relating to planting and replanting of landscaping materials shall apply to the landscaping requirements of this paragraph 6.2.3.1.

\subsubsection{2 $\frac{\text { Screening of Hy View and }}{\text { Trantra Subdivisions. }}$}

Upon the written request of the City Manager, with the concurrence of the City Council, Flatiron will construct any one of the following devices intended as a visual screen between the premises and Hy View Subdivision and Tantra Subdivision:

(a) a fence no more than seven feet in height, constructed of wood, to be reasonably maintained by flatiron so long as mining is being carried on within the premises; or (b) an earthern berm no more than seven feet in height, which shall be planted to grass in the same manner as reclaimed areas which are to be planted tn grass; or (c) not more than thirty clumps of trees, with no more than five trees per clump, each tree to be not more than 2" caliper when planted, trees to be cottonwoods, Russian olives, elms, or a mixture of same. Flatiron will construct an adequate drip irrigation system for the trees and operate and maintain same for three years after date of planting. Planting will be performed in the same manner as required for planting of trees in areas to be reclaimed. 
The visual screen will be located on west boundary of the Flatiron property where same is immediately east of the easterly boundary of Lots Ten through Thirty, Block One, Hy View Subdivision, and immediately east of the eastern boundary of same extended south 300 feet, and on the west boundary, of the Flatiron property where the same is immediately east of the east boundary of Tantra Subdivision, for a distance of about 1,500 feet, or such lesser area is designated by the City Manager with the concurrence of the City Council.

\section{6. ̈.4 Bonding of Landform Construction and} Landscaping.

Prior to commencement of mining or preparatory operations in any stage, Flatiron shall provide to the City and pay the premium for a performance bond in the form set forth in Appendix D (deleted from this report), or substantially similar form reasonably satisfactory to the City Manager. The bond shall be issued by a surety company authorized to do business in the State of Colorado, or other surety reasonably satisfactory to the City Manager of the City. The performance bond shall cover all Flatiron's obligations to complete its obligations pursuant to paragraphs 6.2.1 and 6.2.2 and the appendices associated therewith. The bond for stage one shall also cover Flatiron's obligations in paragraph 6.2.3 and appendix associated therewith.

The amount of the bond shall be 110 percent of the cost of construction of the improvements, including the landforms and cost of purchasing and installing the drip irrigating system, plus 15 percent of the cost of purchasing and planting replacement materials, as estimated by an independent consulting engineer duly registered to practice in Colorado, proposed by Flatiron and approved by the City Manager, which approval shall not be unreasonably withheld. The City shall conduct inspections of the work as from time to time requested by flatiron, and shall authorize releases or reduction in the amount of the bond commensurate with the proportion of the work completed at the time of the inspection.

The bond may cover a period of time less than the maximum permissible time for mining and reclaiming the stage in question, but since the bond obligation includes any necessary, replanting, it shall continue in sufficient amount and time after the initial planting of each stage as set forth in paragraph 6.2 .2 to cover replantings, and the bond may be extended by payment of additional premiums or providing of a substituted bond. If no such extension or substitution is made, Flatiron shall be in default under bond. 


\subsection{Processing, Sale and Removal of Extracted Materials}

Plant Sites; Stockpiles; Accessory Uses.

\subsubsection{Plant Permitted.}

Flatiron shall be permitted to

have and operate on stage five, equipment for crushing, screening, sorting, washing, stockpiling, weighing and loading extracted materials, and such equipment may include, as part thereof, equipment for the extraction of placer gold or other incidental materials association with the sand and gravel. Flatiron shall also be permitted to protect the plant site and remove it from the floodway with a dike pursuant to paragraph 6.10. Flatiron will not process through the plant on the premises more than 15,000 tons per year of materials which are hauled in from outside the premises, except for materials excavated from the existing sand and gravel mine now operated by Loveland Ready Mix, Inc., located immediately south of the premises.

the plant area to create a clean site for the plant, stockpiles, and vehicular movement. This overburden will be used along the north edge of the future lake site in stage one to construct the visual screen referred to in paragraph 6.2.3 Any remaining overburden will be used in stage five to provide a temporary flood control berm for protection of the plant site during its operation.

\subsubsection{Settling Ponds Permitted.}

Flatiron shall be permitted to construct and operate settling ponds on stage five as shown on Appendix $B$ for the purposes of settling out sediment from water used to wash gravel or reduce dust.

A dewatering trench will be constructed to drain the ground water from the area of the settling pond. When dewatered, this area will be mined and mineral processed by a portable plant and stockpiled in the area established for stockpiles. This mined area will then become the settling pond for the rest of the mining operation. Initial water for washing, as well as a small amount of additional water required to make up for water loss during processing, will be provided from surface water rights or ground waters now utilized on the premises.

The settling pond will be drained as needed and deposited sediment excavated from its bottom. The sediment may be used in constructing the various landforms required by Appendix B. 


\subsubsection{Stockpiles Permitted.}

Stockpiles shall be permitted within stage five, except for stockpiles of material to be used in the reclamation process on any stage, which stockpiles may be located on that stage, and except that until completion of reclamation of stage three, temporary or "surge" stockpiles of unprocessed raw material may be located in the southernmost 20 acres of stage three and the northernmost one-half of stage four. Mining of stage two south will not be commenced until the stockpiles have been removed from stage three. Height of stockpiles shall be limited to a maximum of 35 feet. No materials from off the premises will be stockpiled on the premises, except materials excavated from the existing sand and gravel mine now operated by Loveland Ready Mix. Inc., located immediately south of the premises.

\subsubsection{Accessory Uses Permitted.}

Flatiron shall be permitted to have and operate within stage five, an office (where sales of extracted material may be made), a scalehouse, a scale, and buildings for storing and maintaining equipment.

\subsubsection{Fencing and Security Required.}

Fencing and security shall be provided as described in Appendix $E$ (deleted from this report).

\subsubsection{Site Plan Review Required.}

At the time that the plant design is completed, but prior to the start of construction of plant, Flatiron shall submit plant drawings showing location and elevation, maximum height of all fixed buildings and structures, location of stockpiles and permanent processing equipment, and details of proposed signs and lighting.

The uses set forth in paragraphs 6.3. 1 to 6.3.5, inclusive, are subject to all City codes, ordinances, and regulations, as such may be adopted and amended from time to time.

The special use review drawings dated May, 1975, as revised on September 5, 1975, October 16, 1975, and November 26, 1975, comprise the site plan drawings for this project concerning topography, land use, traffic and circulation systems, intersections with public rights-of-way, dedications, flood and drainage systems, and general and detailed landscaping. 


\subsection{Air Quality.}

\subsubsection{Air Quality Maintenance Procedures.}

Roads from the plant site to be paved public road system will be paved or chip sealed and maintained in an appropriate manner. Roads from the stage being mined to the plant site, and areas within the plant site which are regularly traveled by vehicles, will be adequately sprayed with water during each working day, at least prior to 9:00 A.M., and again prior to 1:00 P.M., so as to thoroughly wet the surface and prevent excessive dust emission, unless the surface is already wet from natural precipitation, and unless the temperature at the time when spraying would occur is below freezing.

Water spray bars will be installed and operated on crushing and screening equipment as follows. There will be two adequate spray bars on the intake conveyor belt of the equipment (the point at which raw material enters the system), one on each end of the belt. Spray bars will be operated whenever the water content of the raw material is less than 7-1/2 (.075) percent, unless the temperature at the time when spraying would occur is below freezing. Flatiron may make tests for the purpose of demonstrating that significant dust is not generated at a lesser water content than 7-1/2 percent and apply to the City Manager (or his delegate) for a determination that the lesser standard shall apply, which determination shall not be unreasonably withheld.

\subsubsection{Air Quality Standards.}

Flatiron shall comply at all times with all applicable state and federal air pollution regulations, and with the terms and requirements of the applicable "Fugitive Dust Emission Permit" as issued by the Colorado Air Pollution Control Division, Department of Health, under terms of Regulation No. 1, Part II. D.4, D.6, D.7, D.9, which state:

No land developer of a new, or owner of an existing construction or land development project shall throughout the duration of the project, disturb or contract or disturb by grading, excavating or depositing on more total surface area than five (5) acres of land (in the aggregate) unless abatement and preventive measures as outlined in Section II D. 9 are being met continually. 
Section II D.7: When a complaint of dust or fugitive dust is registered with the Division by a single complainant or multiple complainants who allege that any dust or fugitive dust obstructs or interferes with the reasonable and comfortable use of his or their property, the Division shall investigate and if the Division finds that such conditions exist, the Division shall issue a citation to the person or persons from whose land or activity the objectionable emission emanates and shall require a fugitive dust control plan containing reasonable control measures where appropriate according to the abatement and preventive measures as outlined in Section II D.9.

Complaints regarding dust or fugitive dust may be registered with the Boulder City-County air pollution control officer at the Boulder City-County Health Department.

\subsubsection{Air Quality Monitoring Procedures.}

In the event that complaints of dust or fugitive dust are registered with the Colorado Air Pollution Control Division, City of Boulder, or Boulder City-County air pollution control officers, Flatiron shall cooperate with the appropriate agency in their investigations of the source of the alleged emissions, as provided for in Regulation No. 1, Part II D.7 of the Colorado Air Pollution Control Act.

To contribute to this investigation and provide quantitative data on dust additions to the ambient air, Flatiron will, upon formal request of the City of County, monitor the concentration of airborne particulate matter at requested locations. Monitoring locations shall be chosen to provide representative samplings of air quality.

Monitoring will be performed by high volume sampler using the approved EPA reference method. Results of the monitoring will be transmitted to the Boulder City-County Health Department until the source of excess emissions is determined and appropriate remedies are applied. 


\subsubsection{High Winds.}

Flatiron will install and operate an anemometer for continuous measurement and recording of wind speed at the plant site. At any time when the mean wind speed, as determined visually from the recorded wind speed trace over the most recent 10-minute period, exceeds 30 miles per hours, then mining, earth moving, and hauling of materials to the plant site will be shut down within stages one and two north. Such operations may be reșumed only when the mean wind speed, determined as above provided, has been less than 30 miles per hour for a continuous period of at least 10 minutes. These provisions are in addition to those contained in paragraph 9.3.3.

\subsection{Water Quality.}

6.5.1 Water Quality Maintenance Procedures-Mining Operations.

During dewatering operations required for the dry mining process, ground water which is pumped or otherwise discharged from dewatering trenches may be discharged into South Boulder Creek. No otier discharges will be made from areas being mined (temporary erosion may occur in tre event of flooding, however). $0 i 1$, grease, human wastes or other deleterious substances shall not be left on the surface of the ground, or placed on or into the ground in such a fashion that they co.17 enter the ground water or be carried into the stream or lake by surface or subsurface runoff.

\subsubsection{Water Quality Maintenance Procedures-- Plant Operations}

No discharges into South Boulder Creek will be made from the plant site (temporary erosion may occur in the event of flooding, however). 0il, grease, human wastes or other deleterious substances shall not be left on the surface of the ground, or placed in the ground in such a fashion that they could enter the ground water or be carried into the stream by surface or subsurface runoff.

The system for washing extracted sands and gravels and spraying of materials being processed will consist of a series of settling ponds and the recirculation of wash water in a closed sysitem so that none of the water is discharged directly to South Boulder Creek. Deposited sediments will be periodically removed from the settling ponds and may be used for reclamation. 


\subsubsection{Water Quality Monitoring Procedure.}

Monitoring of water quality will be done as set forth in "Standard Methods of Examination of Water and Wastewater," lastest edition or succeeding publication, published by the American Public Health Association, or equivalent procedures.

to the Boulder City-County Health Department.

Results of this monitoring shall be transmitted

6.5.4 Water Quality Standards for all Operations.

Water discharged into South Boulder Creek, excluding agricultural waste water and storm runoff, will meet the following standards:

a) The settleable solids in any water discharged into South Boulder Creek shall not exceed 0.5 milliliters per liter (m1/1) (sic)

b) Suspended solids (S.S.), including setteable solids, shall not exceed the following limits after the following dates, in milligrams per liter (mg/1):

$\begin{array}{lc}\text { Date } & \text { S.S. } \\ \text { July 1, } 1975 & 25 \mathrm{mg} / 1 \\ \text { July 1, 1978 } & 20 \mathrm{mg} / 1\end{array}$

c) The turbidity in any water discharged into South Boulder Creek shall not exceed the following limits after the following dates:

$\begin{array}{ll}\text { Date } & \text { Turbidity } \\ \text { July 1, 1975 } & 25 \text { Jackson Units } \\ \text { July 1, 1978 } & 20 \text { Jackson Units }\end{array}$

d) The color in any water discharged into South Boulder Creek shall not exceed the following limits after the following dates:

$\begin{array}{ll}\text { Date } & \text { Color } \\ \text { July 1, 1975 } & 25 \text { Units } \\ \text { July 1, 1978 } & 20 \text { Units }\end{array}$


e) Total oil and grease in any water discharged into South Boulder Creek shall not exceed $10 \mathrm{mg} / 1$.

The foregoing standards shall be interpreted as provided by regulations of the Colorado Department of Health.

Flatiron shall install a monitoring system in accordance with the principles set forth in Appendix $F$ (deleted from this report) to observe the water quality of discharges from the mining and reclamation operations. The monitoring program shall be approved in advance by the City, which approval shall not be unreasonably withheld.

These standards are to be achieved by Flatiron regardless of compliance with paragraphs 6.5.1 and 6.5.2.

These requirements are in addition to, and not in lieu of, state and/or federal water pollution requirements, as such may be established or amended from time to time, and should they be, or become, in conflict with state or federal requirements the more stringent shall apply and, if not contained herein, are made substitute herefor.

\subsection{Acoustical Controls.}

The City noise control ordinance (Section 21-14 of the city Code, as amended from time to time) and related sections, or any succeeding sections of the Code, shall govern noise generated on the premises. For purposes of Section 21-14 (c)(1), the "property on which noise source is located" shall include the property annexed and set forth in Section 3. Areas shall cease to be included within the "property" referred to in Section 21-14(c)(1) when either construction of structures thereon is begun in compliance with Section 7 hereof, or the areas cease to be owned by Flatiron or related entities.

\subsection{Traffic, Roads and Bridges.}

6.7.1 Traffic and Roads within the Plant Site, Mining Areas and between Mining Areas and Plant and Stockpile Sites.

Regular traffic in the premises will be restricted to roadways which are treated for dust control in the manner set forth in paragraph 6.4.1 Regular traffic is that vehicular movement which occurs on numerous occasions on each day between two well-defined points, such as the place where mining is occurring and the stockpile area. 


\subsubsection{Roads Between Plant Site and Public Throughfares.}

Roads between plant sites and public throughfares shall be located as shown on Appendix $G$ (deleted from this report) and shall be surfaced in the manner set forth in paragraph 6.4.1.

\subsubsection{Creek Crossing.}

A crossing across South Boulder Creek sha11 be permitted or required in the discretion of the City Manager with the concurrence of the City Council. If required, it shall be constructed by Flatiron, as shown in Appendix $\mathrm{H}$ (deleted from this report).

\subsubsection{Intersections.}

Intersections on Appendix I (deleted from this report) will be constructed by Flatiron after review and approval of the intersection plans, design and materials by the City Manager of his representative.

\subsubsection{Traffic onto Public Throughfares.}

In view of possible congestion of Table Mesa Drive where the haul road meets Table Mesa Drive/South Boulder Road, the following restrictions are imposed on trucks hauling material from the premises over the haul road which intersects Table Mesa Drive and thereafter proceeding on Table Mesa Drive:

Not more than 10 loaded single axle, tandem, or dump trucks will travel the route described above per hour which falls within the periods between the hours of $7: 30$ A.M. to $8: 30$ A.M. and 4:00 P.M. to 5:30 P.M. Truck traffic during these time shall be spaced to that there is a minimum interval of at least five minutes between trucks entering onto Table Mesa Drive.

\subsection{Plant Operating Hours.}

Normal plant operating hours will be from 7:30 A.M. to 6:30 P.M., Monday through Friday.

Normal hours for sale of materials and hauling of materials from plant site to public streets will be from 7:00 A.M. to 6:30 P.M., Monday through Saturday. No vehicle in excess of one-ton capacity will be permitted to enter or leave the site on Saturday. 
Normal hours for mining and related operations will be from 7:30 P.M. to 6:30 P.M., Monday through Friday.

Except as provided below, the operations referred to above (sale and hauling of materials, plant operations and mining operations) will not be conducted between 6:30 P.M. and 7:00 A.M.

Normal hours for maintenance, repair and cleaning of buildings and equipment shall not.be restricted so long as all applicable City ordinances are complied with.

Flatiron may operate at times other than normal hours whenever reasonably necessitated by fire, flood, windstorm, civil disorder, or local or national emergency, or other casualty or emergency beyond the control of Flatiron, or substantial risk thereof. In such event, Flatiron shall apply to the City Manager for permission to operate outside the hours set forth above, which permission shall not be unreasonably withheld, considering the public health, safety and welfare. In the event of immediate hazard from flood, fire or windstorm, Flatiron may proceed to operate outside the hours set forth above without first obtaining permission, but shall apply for permission as soon as practical.

Flatiron may also be given permission to operate at times other than the required and normal hours herein set forth in the event of unusual scheduling operations due to market conditions and the press of construction schedules. An application will be made by Flatiron for the exception to the City Manager. The exception will be granted if the City Manager and the City Council in their sole and absolute discretion deem it appropriate in the circumstances. 


\subsection{Water Distribution and Useage.}

The water supply plan for the reclaimed area shall be based on retaining water rights presently used for pasture irrigation on the existing site, and converting their application to irrigation, stream and lake preservation and recreation. Stream depletions will be equated to historic depletion by balancing land use under critical and average-year conditions. Water supply to maintain lake levels and circulation within the lake system will be derived from ground water and surface runoff of portions of the area tributary to the site, and from irrigation water historically used on the premises. In addition, some return flow from irrigation by water from the Dry Creek No. 2 Ditch will be available to the lake. Inflow/outflow sudies for the critical period 1953 through 1955 indicate that sufficient ground water and surface water runoff was available to maintain an adequate flow through of water in the lake to be constructed in stage one. It is anticipated that in periods of less than average moisture, lake levels and marsh areas may decrease somewhat in accordance with the natural cycle common to a semiarid climate such as exists in Boulder, Colorado. Water use areas will be balanced so there is no net increase in stream depletion or adverse effect on other water rights. Lake levels will be established and maintained so as to prevent significant interference with historic ground water flow patterns to South Boulder Creek or loss of water from South Boulder Creek to excavated areas.

Dewatering operations during gravel extraction will be conducted in such a manner as to not interfere with wells on adjacent property. Flatiron shall install an approved monitoring system in accordance with paragraph 6.5 .4 to determine whether its operations are adversely affecting such wells. The monitoring system shall be approved in advance by the City, which approval may not be unreasonably withheld. In the event the monitoring system indicates any significant adverse effect on any existing, off-site wells, Flatiron shall immediately take appropriate measures to insure and sustain the affected water level in those wells.

Dewatering, mining and reclamation will result in periodic or permanent lowering of ground water levels in areas mined and in some areas adjacent to those mined.

A11 necessary measures as shown on Appendices $B$ and $H$ (deleted from this report), including construction of impervious areas and shale layers on embankment slopes, will be undertaken to correct any significant adverse effect on water levels in South Boulder Creek. Underground flow and leakage from the main lake will be reduced by construction as shown on Appendices $B$ and $J$ (deleted from this report). 
The Dry Creek No. 2 Ditch will be relocated in accordance with Appendices $B$ and $K$ (deleted from this report), subject to approval by the ditch company.

A portion of the water historically used on the premises will be used for washing of sand and gravel and dust control measures.

\subsection{Flood Control and Drainage.}

The historic flow patterns of South Boulder Creek and Dry Creek No. 2 Ditch downstream of the site and adjacent to the site will not be significantly altered by the mining and reclamation activities. Gravel excavations and final land configurations will create temporary flood storage that will moderate peak flood flows. A series of channels, ponds and lakes will carry ground water from the reclaimed land areas to South Boulder Creek. Mining and plant facilities, including stockpiles, will be placed above the 100-year flood elevation or protected by berms. None of the on-site activities will add to debris accumulation during flooding.

Flatiron shall construct, as part of the reclamation of the relevant stages, the following structural improvements as shown on Appendices B and K: The low flow discharge and overflow spillways for each of the two ponds and lake, the lake berm, internal drainage facilties (but no culvert crossings or crossings over overflow structures); the Dry Creek Ditch relocations, the flood diversion dikes and the drain inlets. Structural improvements as part of the drainage plan include only those improvements or facilities necessary for flood control or drainage.

A temporary flood control measure is a protective dike around the plant site and wash water settling ponds to remove them from the 100-year flood plain. The Dry Creek No. 2 Ditch will require a temporary relocation during the early stages until completion of the north and west lake berms, and will then be relocated by Flatiron to its permanent position as shown in Appendices B and $\mathrm{K}$. 
Section 7. Restrictions and Requirements on Adjacent Property.

7.1 Restrictions on Construction of Structures on Adjacent Property.

No applications and plans for construction of new structures will be processed on the property described on Appendix $L$ (deleted from this report), until completion of mining and reclamation on stage two north. No applications and plans for construction of new structures will be processed on the property described on Appendix $M$ (deleted from this report), until completion of mining and reclamation of stage two north. No applications and plans for construction of new structures will be processed on the property described on Appendix $N$ (deleted from this report), until completion of mining and reclamation of stage two south.

Roads described herein, alterations of the contour of the land and flood control or drainage facilities shall not be deemed to be structures.

\subsection{Reclamation of Adjacent Areas.}

On or before June 15 which follows granting of this approval by 45 or more, Flatiron will plant Foothills Mix grass seed on the area described in Appendix 0 (deleted from this report), except for areas then covered by stockpiles of material, roadways, and areas used for loading and removal of stockpiled material. When stockpiled material have been removed, Flatiron will similarly plant remaining unplanted areas on the first June 15 which follows such removal by 20 days or more. Bare spots which exist on the first March 30 which is more than three months after date of planting will be appropriately reseeded by Flatiron on or before the following June 16 .

The air quality maintenance procedures set forth in paragraph 6.4.1 shall apply to the area described in Appendix 0 until reclaimed as above described.

7.3 Irrigation of Deepe Farm Site.

During dewatering and mining of stage four, Flatiron will adequately irrigate the trees and shrubs on the Deepe farm site. 
Section 8. Insurance.

Until completion of all mining and reclamation, Flatiron will name the City as an additional insured on its public liability insurance policies with regard to the subject property, which policies shall be made available to the City Manager. Said policies sha 11 have coverage and limits reasonably acceptable to the City Manager, and in any event, limits no less than $\$ 500,000$ per person, per accident.

Section 9. Enforcement of the Conditions of the Approval.

9.1 Conditions of Approval to be Part of the Zoning Map and Ordinance Applicable to the Premises.

The conditions imposed herein upon the use permitted are imposed under the provisions of Section 37-402(d), 37-402(f) and 37403(b) of the City Code, are a part of the site plan of the premises, and become a part of the zoning map and zoning ordinance applicable to the premises pursuant to Section $37-402(h)$ of the City Code.

\subsection{Inspections of the Premises.}

9.2.1 Regular Annual Inspections.

The City Manager of his delegate shall make regular, annual inspections of the premises between May 15 and June 16 of each year and adivse Flatiron of any deficiencies noted and the results of the inspection shall be made available to the City Council and the public.

\subsubsection{Discretionary Inspections.}

Upon complaint of any citizen, or upon the initiative of the City Manager, the City Manager of his delegate or representatives of the Boulder City-County Health Department may inspect the premises at any time.

\subsubsection{Inspections for Purposes of Release from Bonds.}

Upon request of Flatiron, the City Manager or his delegate shall promptly inspect reclaimed areas for purposes of determining whether any bond should be released in whole or in part (see paragraph 6.2.4). 


\subsection{Sanctions for Violations of Conditions.}

\subsubsection{Fines.}

Fines for violation of any of the conditions imposed by this approval may be imposed under Sections 37-901 and 37-902 and related provisions of the City Code, as from time to time amended or superseded, such fines to be imposed in the same manner as fines for other violations of the zoning ordinance.

\subsubsection{Injunctive Relief.}

The City may seek injunctive relief against any violation of any of the conditions imposed by this approval under Section 37-901 (a) (4) and ( $f$ ) and related provisions of the City code, as from time to time amended, such injunctive relief to be obtained in the same manner as injunctive relief for other violations of the zoning ordinance.

\subsubsection{Shutdown of Operations.}

In the event of a violation of any of the conditions set forth herein which by its nature is continuous (such as but not limited to failure to properly perform reclamation within required time limits, mislocation of a plant site, or failure to install proper dust-control equipment), the City Manager, upon receiving the concurrence of the City Council, may order some or all of the operations on the premises to be shut down, in the following manner: The City Manager shall hold a hearing on the proposed shutdown, at which Flatiron shall be permitted to present evidence and cross-examine witnesses. Flatiron shall be given a written notice of the hearing at least 20 days in advance of the hearing. This notice shall state with particularity the alleged violation or violations which will be raised at the hearing. Testimony at the hearing shall be given under oath. In the event that the City Manager determines upon substantial competent evidence that a continuing violation exists, the City Manager, upon receiving the concurrrence of the City Council, may order the offending portion of the operations or any relevant portion thereof shut down until the violation is corrected. In the event of a violation which consists of failure of Flatiron to comply with its obligations to construct landforms or drip irrigation systems or plant or replace landscaping materials, mining operations may be shut down until the violation is corrected. Work necessary to correct the violation may proceed, however. In the event of a continuing violation which constitutes an immediate and serious threat of bodily injury, damage to public health or satety, unforeseen environmental impact or property damage, the 20 -day notice need not be given and the City Manager will not need the concurrence of the City Council, and only such notice need not be given and the City Manager will not need the concurrence of the City Council, and only such notice need be given as is reasonable in view of the nature of the threat of bodily injury, damage to public health or safety, unforeseen environmental impact or property damage. 
Any shutdown pursuant to this paragraph shall not alter the time schedule set forth in paragraph 6.1.2.

These provisions are in addition to those contained in paragraph 6.4.4.

\subsubsection{Provisions and Sanctions not Exclusive.}

Nothing herein shall operate to release or excuse Flatiron from complying with the provisions of the Revised Code of the City of Boulder, 1965, as amended, and as it may be amended from time to time. In the event that Flatiron violates any provision of the Code which gives rise to civil or criminal remedies different from those set forth in paragraphs 7.3.1 to 7.3.3, inclusive, the City may elect to proceed under this permit or under the relevant section or sections of the Code.

Section 10. Such part only of said Chapter 37, "Land Use Regulations," of the Revised Code of the City of Boulder, 1965, as amended, in conflict herewith, be, and the same hereby is, superseded.

Section 11. It is the intention hereof that this ordinance not be severable. Therefore, should any part of parts hereof be for any reason held to be invalid, such shall defeat the entire ordinance.

Section 12. The City Council finds that this ordinance is necessary to and for the benefit of the public interest, public health, safety and welfare; under Charter Section 18 (a) it is deemed by the City Council that publication be by title of the ordinance only together with a short outline of topics therein and a statement that the published text is available for public inspection and acquistion in the office of the City clerk.

(Attesting and signatures omitted) 


\section{APPENDIX C}

EXCERPT FROM CLEAR CREEK COUNTY ZONING RULES

AND DESCRIPTIVE REGULATIONS,

PHILLIPS, BRANDT, REDDICK, CONSULTANTS

Section 17. M-1 MINING ONE DISTRICT

A. USE REGULATION

No building or land shall be used and no building shall be hereafter erected, converted or structurally altered, unless otherwise provided herein, except for one or more of the following uses;

1. Any use specifically required for the mining, prospecting, exploring, milling and/or placering of mineral resources upon property defined by a patented mining claim or mill site, or identified by a location certificate recorded in the County Clerk and Recorder's Office, all as represented by maps approved by the Board of County Commissioners.

2. Any use specifically required for the mining, prospecting, exploring, milling and/or placering of mineral resources upon property or adjacent to property defined in Section $17 \mathrm{~A} .1$. above and classified according to Section 25 C. 15 , or upon property identified by a location certificate and classified according to Section 25 C. 15.

3. Such other uses which are not more detrimental to the highest and best uses of land in said district than are the uses hereinbefore enumerated.

B. HEIGHT REGULATION

None. 


\section{AREA REGULATION}

Property abutting Residential Uses Subject to the provisions of Section 25 C. 12. No use causing an objectionable odor, noise or dust shall be permitted within five hundred (500) feet of the property boundary of: (1) a residence existing as of September 20, 1976; (2) property for which a residential building permit has been issued on or before September 20, 1976; or (3) a residential subdivision which has received final plat approval on or before September 20, 1976. 


\section{. TH: TO:}

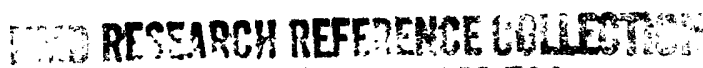

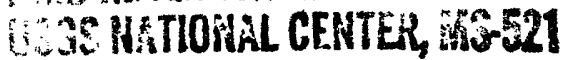

AEv N, VA. 22072

421(271)

Im3 Imhoff, Edgar A.

\begin{tabular}{cl}
\hline AUTHOR & \multicolumn{1}{c}{ A review of selected } \\
& laws and governmental \\
\hline TITLE & $\begin{array}{l}\text { programs in Colorado, as } \\
\text { related to mineral resourg }\end{array}$ \\
\hline DATE DUE & managemegtroapf surface
\end{tabular}

DATE DUE

\begin{tabular}{l|l|l|l}
\hline & & & \\
\hline & & & \\
\hline & & & \\
\hline & & & \\
\hline & & & \\
\hline & & & \\
\hline & & & \\
\hline & & & \\
\hline & & & \\
\hline & & & \\
\hline
\end{tabular}


